\title{
Diversity and Abundance of Intertidal Rove Beetles (Coleoptera: Staphylinidae) in Bachok coast, Kelantan, Malaysia.
}

\section{Fauziah Abdullah}

Institute of Biological Sciences, Faculty of Science, University of Malaya, 50603 Kuala Lumpur, Malaysia. fauziah@um.edu.my (corresponding author) Received on $22^{\text {nd }}$ July 2009, accepted in revised form $28^{\text {th }}$ October 2009.

\begin{abstract}
A study on the fauna of intertidal rove beetles (Coleoptera:Staphylinidae) was conducted from $30^{\text {th }}$ May to $7^{\text {th }}$ June 2009 in the Bachok coast, Malaysia. Collections were conducted at seven beaches, namely Nipah Beach, Irama Beach, Melawi Beach, Tok Bali Beach, Tanjung Chap Beach, Kemasin Beach and Perupok Beach. A total of 885 intertidal rove beetles comprising 34 species were collected from all seven sites of the Bachok coastal area. There was low species richness (Margalef index: 4.857) and high diversity of intertidal rove beetles (Simpson index: 0.906). Five identified species are new records for the Bachok coast, namely, Paederus fuscipes, Gymnusa atra, Tetraticta potita, Anorylus insecatus and Paederus sondaicus. Twenty-six species identified to family level are probably new to science. This first study ever conducted at Pantai Bachok shows that Bachok coastal area has a high diversity of intertidal rove beetles.
\end{abstract}

\begin{abstract}
ABSTRAK Fauna kumbang antara pasang surut (Coleoptera:Staphylinidae) telah di kaji dari $30^{\text {hb }}$ Mei hingga $7^{\text {hb }}$ Jun 2009 di pesisiran pantai Bachok, Malaysia. Penyampelan di lakukan di tujoh pantai: Pantai Nipah, Pantai Irama, Pantai Melawi, Pantai Tok Bali, Pantai Tanjung Chap, Pantai Kemasin dan Pantai Perupok. Sejumlah 885 kumbang terdiri dari 34 species telah di kutip dari tujoh pantai tersebut. Terdapat kelimpahan dan kekayaaan species yang rendah (Margalef indeks: 4.857) dan kepelbagaian yang tinggi (Simpson indeks: 0.906) kumbang Staphylinid bagi keselurohan kawasan kajian. Lima species telah dikenalpasti merupakan rekod baru untuk kawasan pesisiaran pantai Bacok iaitu: Paederus fuscipes, Gymnusa atra, Tetraticta potita, Anorylus insecatus dan Paederus sondaicus. Dua puloh enam spesies hanya di identifikasi ke tahap family berkemungkinan adalah spesies baru Kajian yang ulong kali dijalankan di Bachok ini menunjukkan bahawa Pantai Bachok mempunyai kumbang pesisiran pantai yang tinggi kepelbagaiannya.
\end{abstract}

(Keywords: Intertidal rove beetle, Staphylinidae, Abundance, Bachok)

\section{INTRODUCTION}

The beetle family Staphylinidae commonly known as rove beetle represents one of the truly remarkable radiations in the history of life. It currently includes over 46,200 described species, placed in 3200 genera and organized into about 32 subfamilies [1].

Majority of the coastal beetle diversity is composed of the members of the family Staphylinidae, and particularly its large subfamily Aleocharinae, which is represented by approximately 400 species throughout the world $[2,3] .442$ species in 102 genera and 7 subfamilies are known to be confined to seashore habitats $[2,3,4]$.

Maruyama et al. [5] reported that the true intertidal species are specialized to live in low to high tide zones. Studies of insects along the seashore have also been conducted by Wong and Chan [6]. These investigated staphylinids are not considered to be marine in the true sense being occasionally washed by the high tides around sand dunes or submerged in sea water temporarily.

With lack of study on intertidal staphylinids in Malaysia, this intensive study was conducted to determine the abundance and diversity of intertidal rove beetles at the coastal areas in Bachok, Kelantan, Malaysia and to provide a checklist and documentation of intertidal staphylinids.

\section{MATERIALS AND METHOD}

\section{Study Sites}

Field observations were carried out from $30^{\text {th }}$ May to 7 June 2009 at Bachok coastal area, Malaysia during high tides and low tides from $0800 \mathrm{~h}$ to $1400 \mathrm{~h}$. The study sites were at Pantai Irama $\left(6^{\circ} 032.4^{\prime} \mathrm{N}\right.$, $\left.102^{\circ} 23.5^{\prime} \mathrm{E}\right)$, Pantai Nipah $\left(6^{\circ} 032^{\prime} \mathrm{N}, 102^{\circ} 24.2^{\prime} \mathrm{E}\right)$, Pantai Tanjung Chad $\left(6^{\circ} 025^{1} \mathrm{~N}, 102^{\circ} 24.6^{\prime} \mathrm{E}\right)$, Pantai Melawi $\left(6^{\circ} 020^{\prime} \mathrm{N}, 102^{\circ} 25.2^{\prime} \mathrm{E}\right)$, Pantai Tok Bali $\left(6^{\circ} 015^{\prime} \mathrm{N}, 102^{\circ} 27.5^{\prime} \mathrm{E}\right)$, Pantai Perupok $\left(6^{\circ} 10.0^{\prime} \mathrm{N}\right.$, $\left.102^{\circ} 22.9^{\prime} \mathrm{E}\right)$ and Pantai Kemasin $\left(6^{\circ} 75^{\circ} \mathrm{N}, 102^{\circ} 22^{\prime} \mathrm{E}\right)$. 


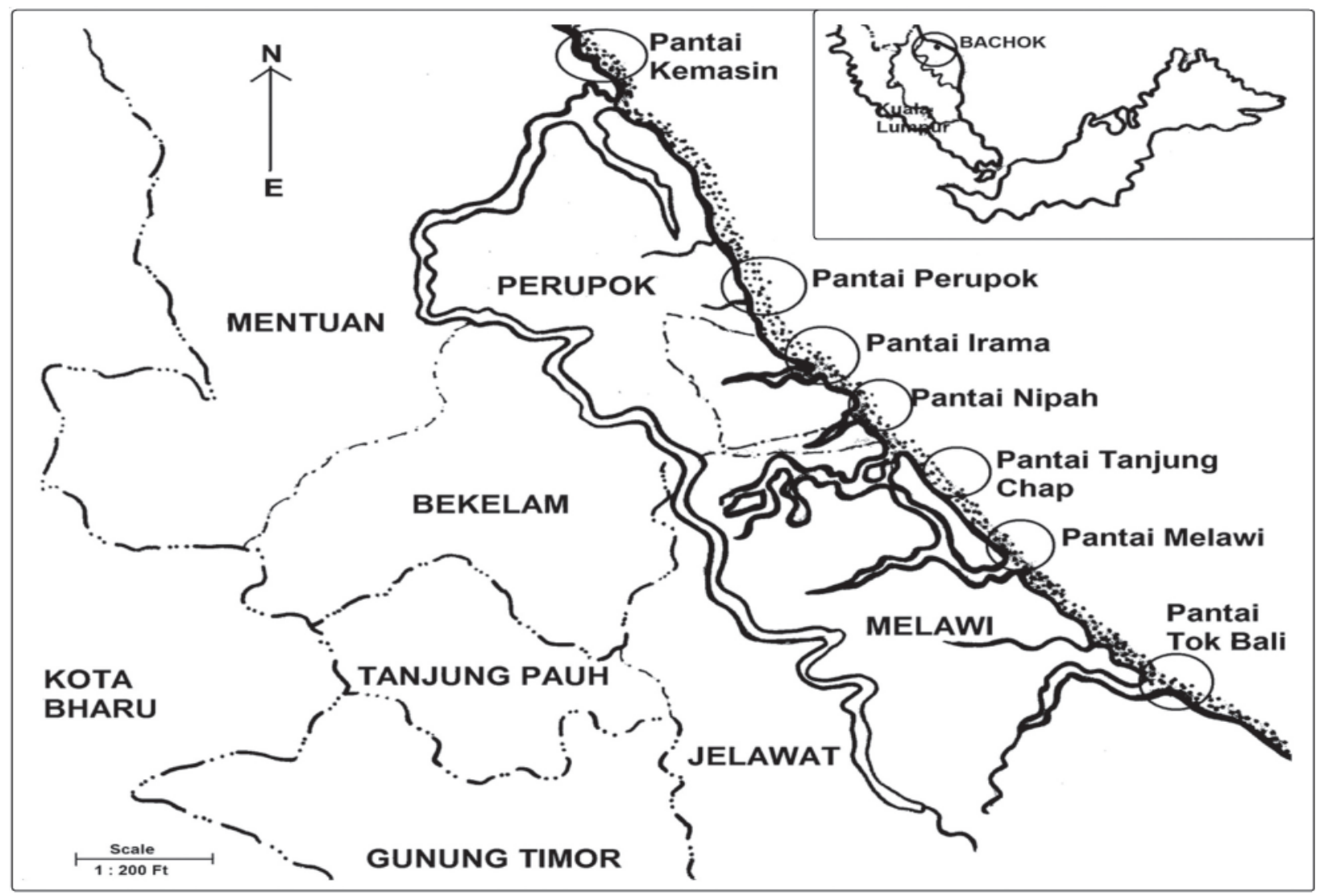

Figure1. Study sites at selected coastal areas of Bachok, Kelantan

\section{Sampling and Observation Method}

At each study site from $0800 \mathrm{~h}$ to $1300 \mathrm{~h}$, two sampling plots of $50 \mathrm{mX} 50 \mathrm{~m}\left(2500 \mathrm{~m}^{2}\right)$ were set up using raffia rope near to the edge of sea water during low tide. Within the sampling plot, five quadrats of 1 $\mathrm{m} \mathrm{X} 1 \mathrm{~m}$ were randomly laid. In the quadrat, sand was collected from depths of $1 \mathrm{~cm}, 2 \mathrm{~cm}, 20 \mathrm{~cm}$ and $30 \mathrm{~cm}$. The sand was sieved through a wire strainer and searched for rove beetles using a hand lens. At Bachok coastal area, low tide began at $0342 \mathrm{~h}$ followed by high tide at $1148 \mathrm{~h}$, and then another low tide at $2030 \mathrm{~h}$ and high tide at $2250 \mathrm{~h}$.

\section{Light trap}

Four light traps were set up $100 \mathrm{~m}$ from each other in series, starting $10 \mathrm{~m}$ from the sea water before nightfall at 17:30 h (Figure 2). Due to strong wind at the beach two poles secured the net to the ground. A 100 watt mercury bulb provides the light source. The generator was switched on from 19:00 h to $2300 \mathrm{~h}$. The rove beetles were collected using pill bottles and aspirator.

\section{Preservation and Identification}

Staphylinid beetles were sorted and preserved in $70 \%$ alcohol and brought back to laboratory for pinning.
At University of Malaya, the Staphylinid beetles were pinned, dried at $40^{\circ} \mathrm{C}$ in oven, properly labelled and identified using several reference books. Cross references were done with collections from Department of Agriculture, Peninsular Malaysia, Kuala Lumpur. Margalef Species Richness index, Simpson Diversity index and Shannon-Weaver Diversity index were used to calculate the species richness and diversity of staphylinid beetles.

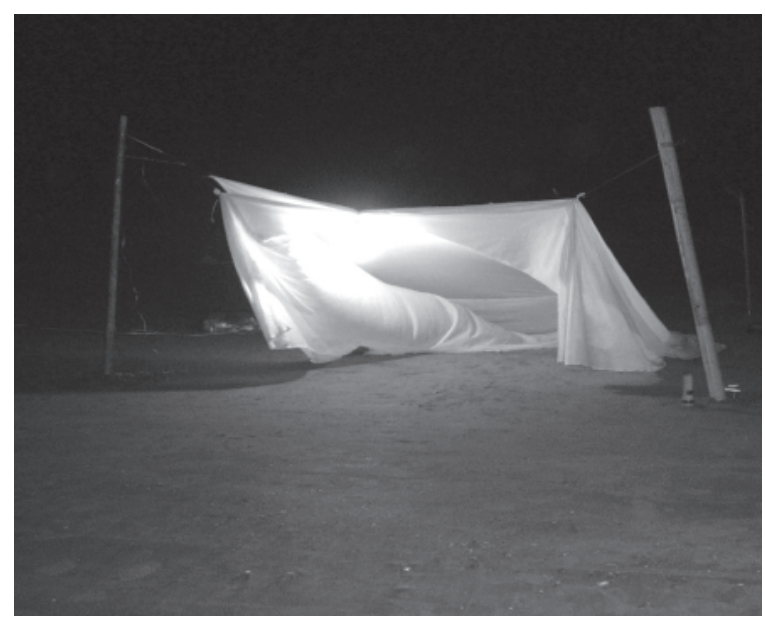

Figure 2. Light trap at the beach. 


\section{RESULTS}

\section{Quadrat sampling}

At all seven beaches and within two $50 \mathrm{~m} \mathrm{X} 50 \mathrm{~m}$ sampling plots, sieved sand collected from twenty 1 $\mathrm{m} \mathrm{X} 1 \mathrm{~m}$ quadrats at depths of $1 \mathrm{~cm}, 2 \mathrm{~cm}, 20 \mathrm{~cm}$ and $30 \mathrm{~cm}$ from the beach surface, did not yield any staphylinids.

\section{Light Trapping}

A summary of specimens of rove beetles collected by light trapping at seven beaches at Bachok coastal areas in Kelantan, Malaysia is given in Table 1.
A total of 885 individuals from 34 species of rove beetles were sampled from $30^{\text {th }}$ May to $7^{\text {th }}$ June 2009. At Pantai Kemasin 104 specimens from 17 species were assembled, 123 specimens from 14 species at Pantai Perupok, 91 specimens from 13 species at Pantai Nipah, 73 specimens from 10 species at Pantai Irama whereas 184 specimens from 20 species were sampled at Pantai Tanjung Chap, 166 specimens from 22 species were sampled at Pantai Melawi and 144 specimens from 13 species at Tok Bali.

Table 1. A summary of staphylinds collected at different study sites at Bachok coastal area.

\begin{tabular}{lll}
\hline Study Site & Individual & Species \\
\hline Pantai Kemasin & 104 & 17 \\
Pantai Perupok & 123 & 14 \\
Pantai Nipah & 91 & 13 \\
Pantai Irama & 73 & 10 \\
Pantai Tanjung Chap & 184 & 20 \\
Pantai Melawi & 166 & 22 \\
Pantai Tok Bali & 144 & 13 \\
\hline Total & $\mathbf{8 8 5}$ & $\mathbf{3 4}$ \\
\hline
\end{tabular}

Table 2. Abundance and diversity of intertidal Staphylinidae at Bachok coastal area.

\begin{tabular}{llll}
\hline STUDY SITE & Margalef Index & $\begin{array}{l}\text { Simpson } \\
\text { Diversity Index }\end{array}$ & Shannon Weaver Index \\
\hline Pantai Kemasin & 3.445 & 0.999 & 2.479 \\
Pantai Perupok & 2.701 & 0.880 & 2.245 \\
Pantai Nipah & 2.817 & 0.661 & 1.651 \\
Pantai Irama & 2.098 & 0.741 & 1.616 \\
Pantai Tanjung Chap & 3.643 & 0.881 & 2.392 \\
Pantai Melawi & 4.108 & 0.895 & 2.494 \\
Pantai Tok Bali & 2.415 & 0.746 & 1.752 \\
\hline
\end{tabular}

Pantai Melawi was species richest (Margalef index : 4.108), followed by Pantai Tanjung Chap, Pantai Kemasin, Pantai Nipah, Pantai Perupok, Pantai Tok Bali and Pantai Irama (Margalef index : 3.643; 3.445 ; 2.817; 2.701; 2.415; 2.098). However, Pantai
Kemasin was the most diverse (based on Simpson Diversity Index : 0.999) followed by Pantai Melawi (0.895), Pantai Tanjung Chap (0.881), Pantai Perupok (0.880), Pantai Tok Bali (0.746), Pantai Irama (0.741), and Pantai Nipah (0.661). 


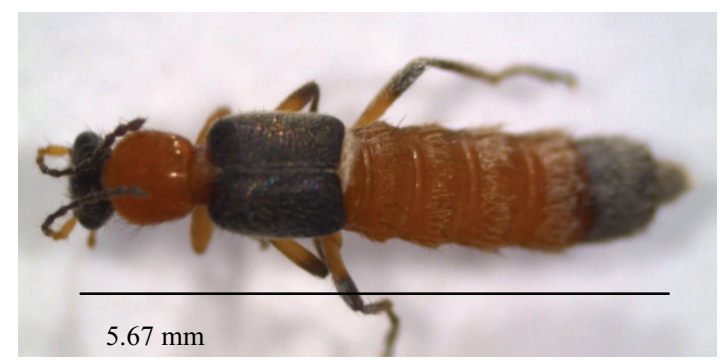

a. Paederus fuscipes Curtz

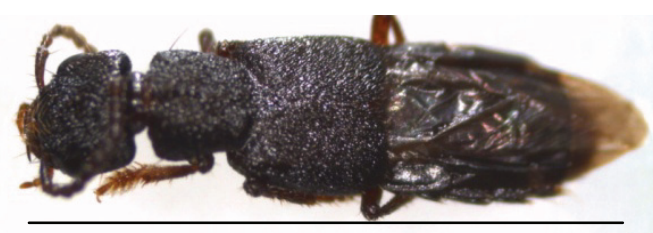

$6.77 \mathrm{~mm}$

c. Gymnusa atra

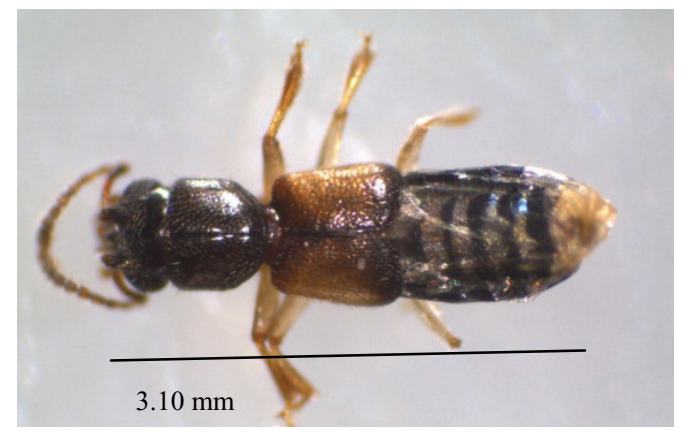

e. Anorylus insecatus

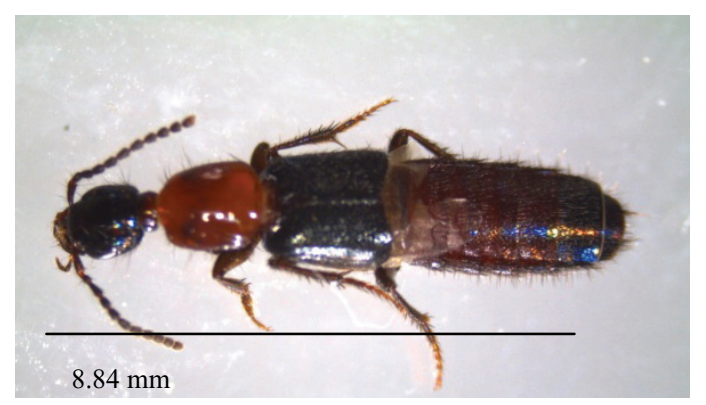

g. Paederus sondaicus Fauv

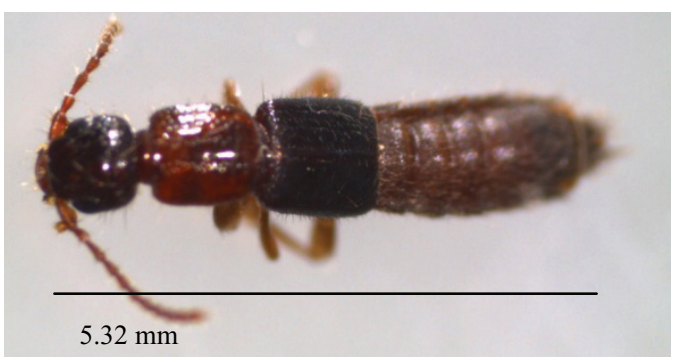

b.Paederus $\mathrm{sp} 1$

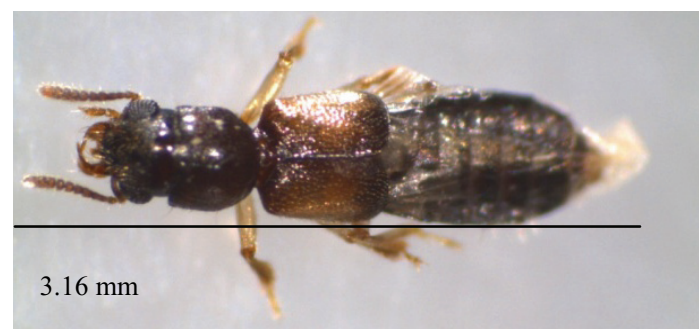

d. Tetraticta potita $\mathrm{Ki}$

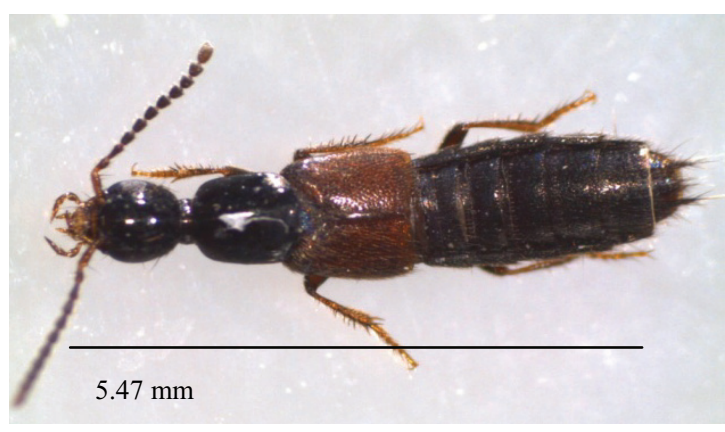

f. Acrotona sp

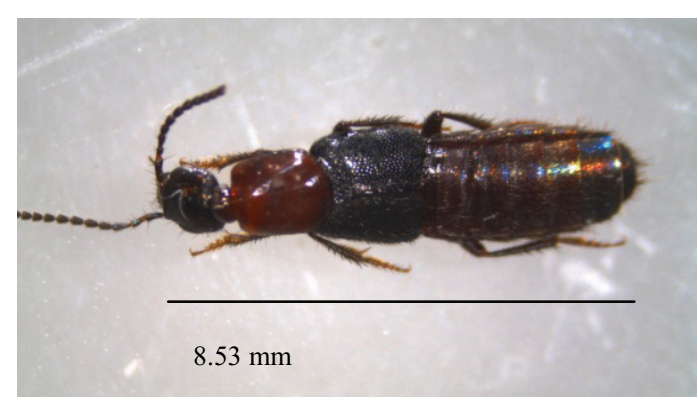

h. Paederus sp2

Figure 3a-h. Identified intertidal rove beetles from Bachok's coast. 


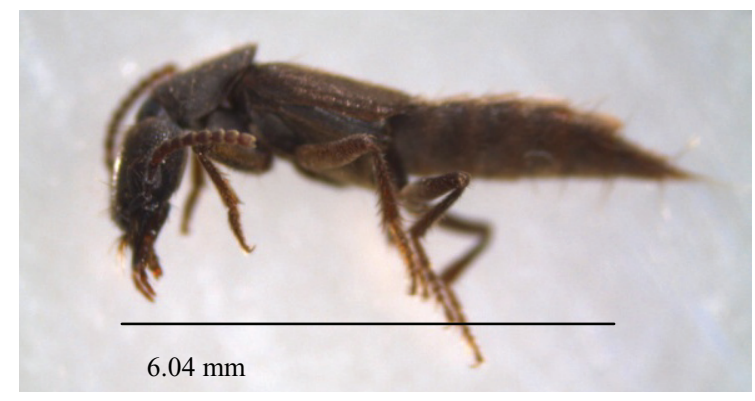

a. Staphy sp1

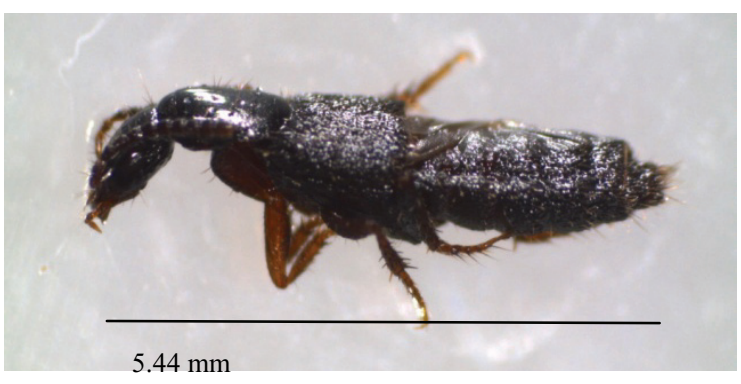

c. Staphy sp3

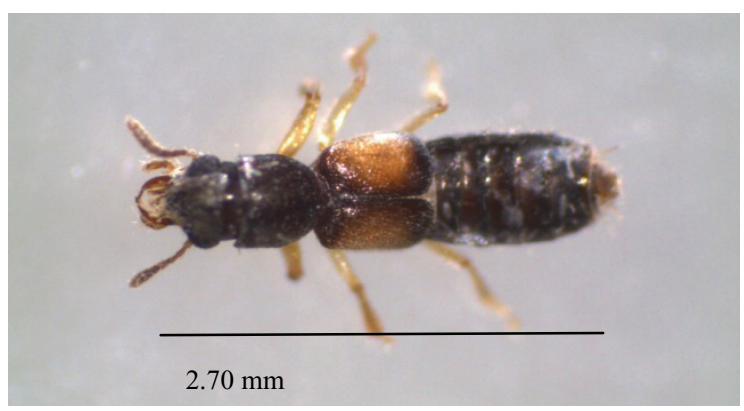

e. Staphy sp5

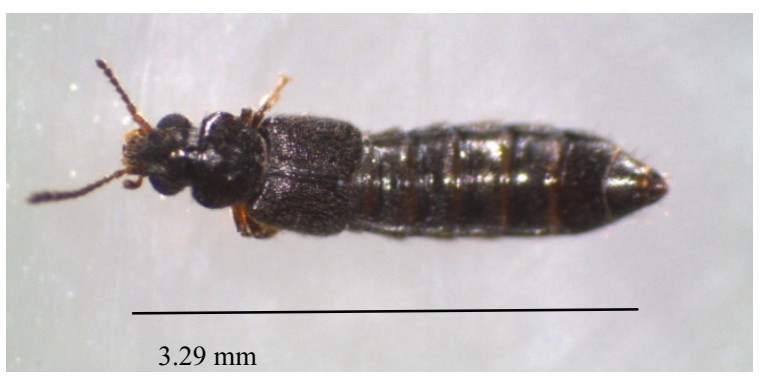

g. Staphy sp7

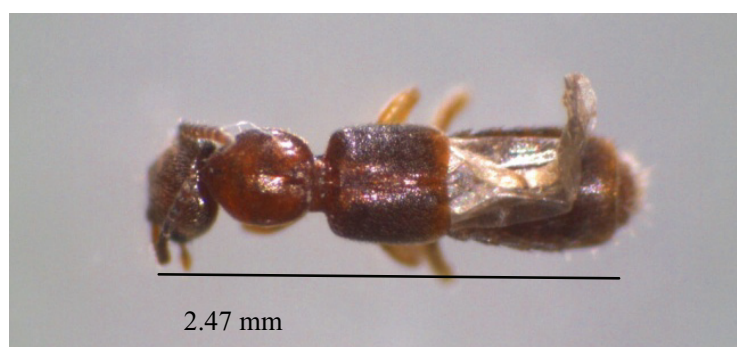

i. Staphy sp9

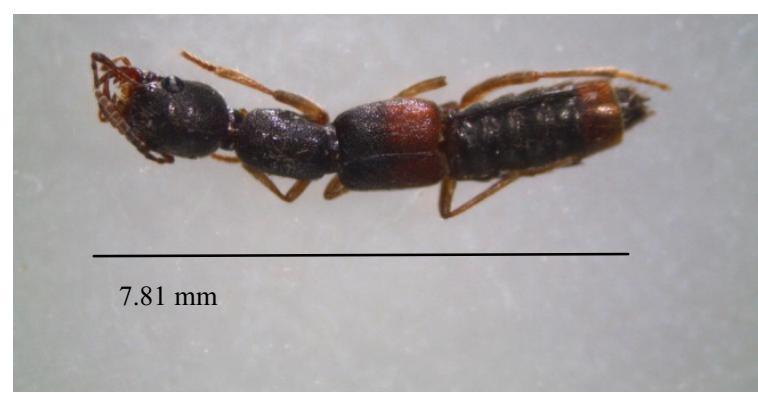

b. Staphy sp2

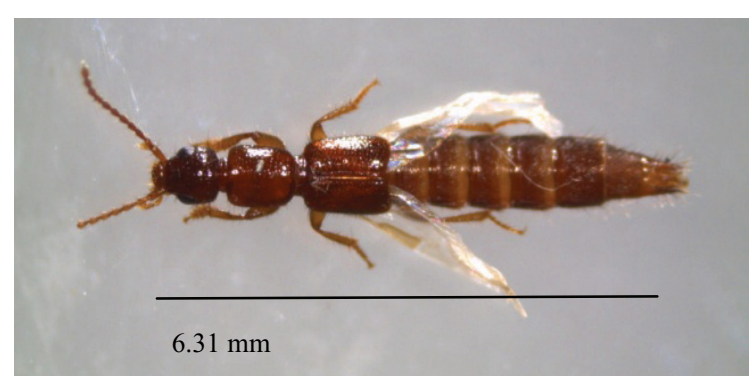

d. Staphy sp4
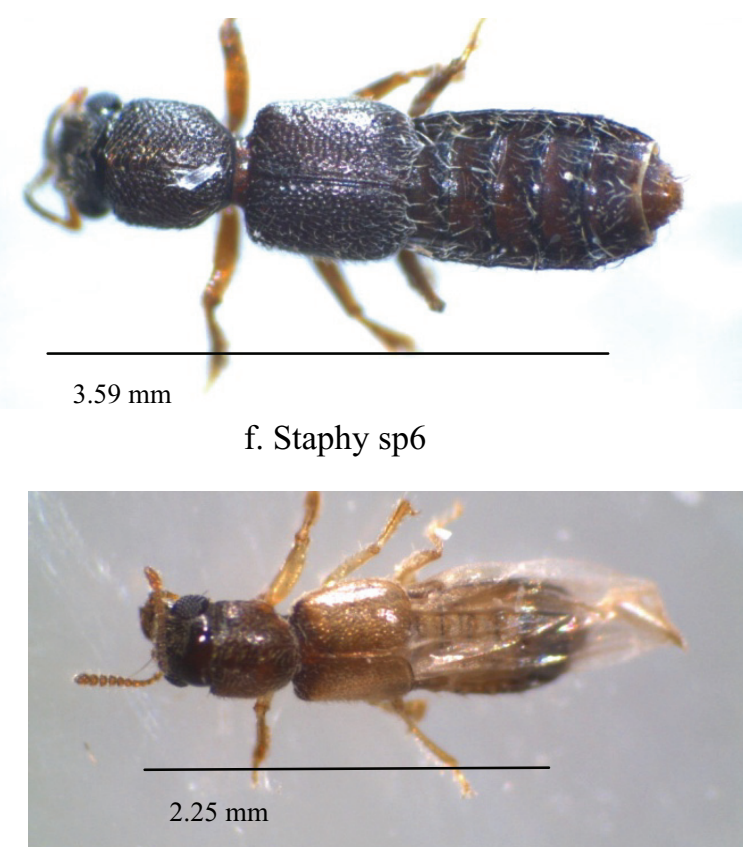

h. Staphy sp8

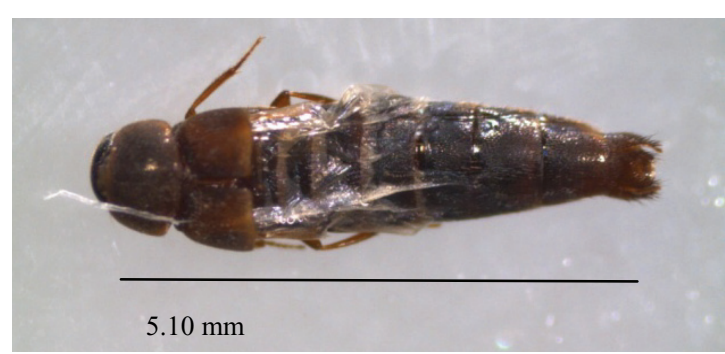

j. Staphy sp10 


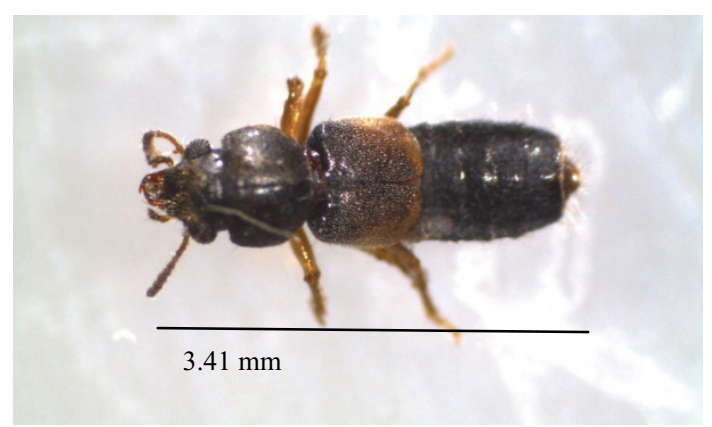

k. Staphy sp11

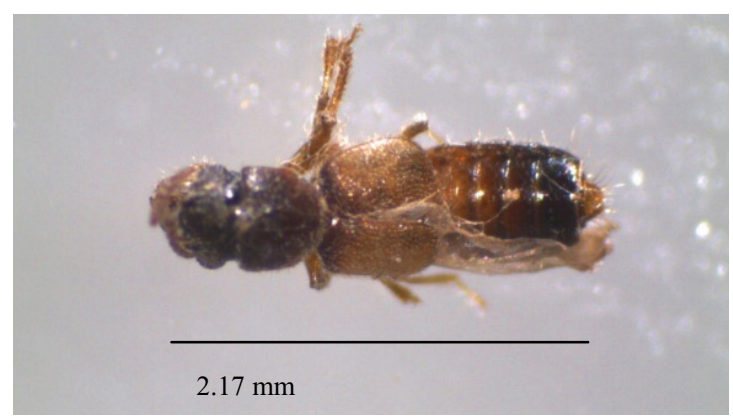

m. Staphy sp13

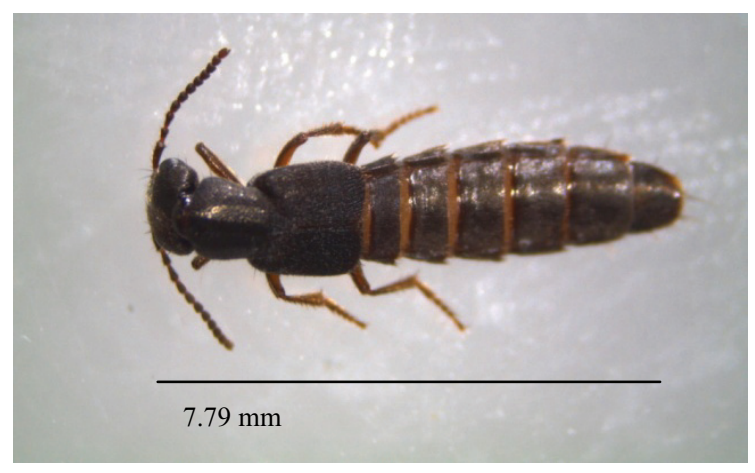

o. Staphy sp15

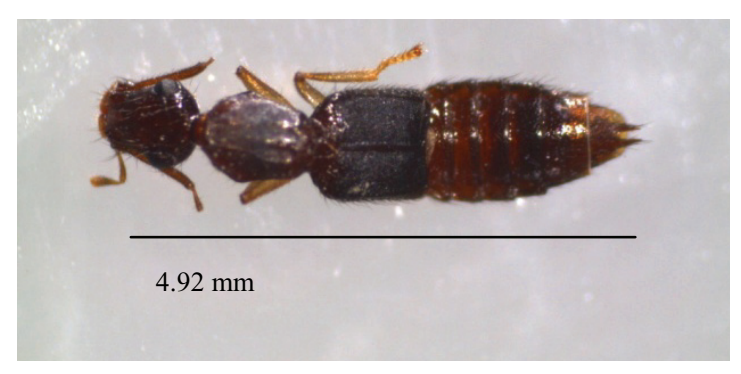

q. Staphy sp 17

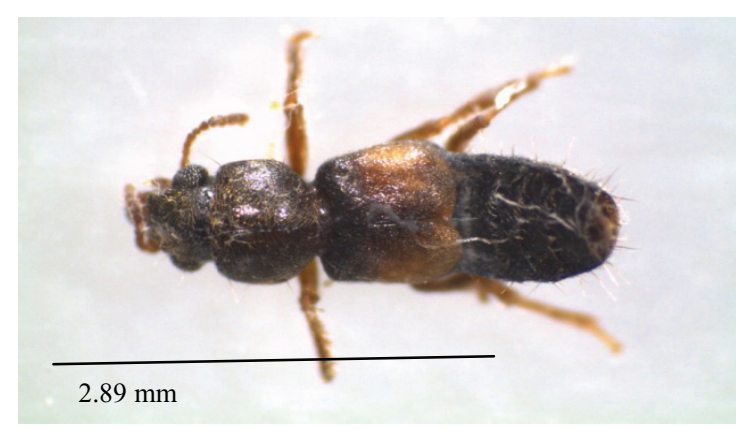

1. Staphy $\mathrm{sp} 12$

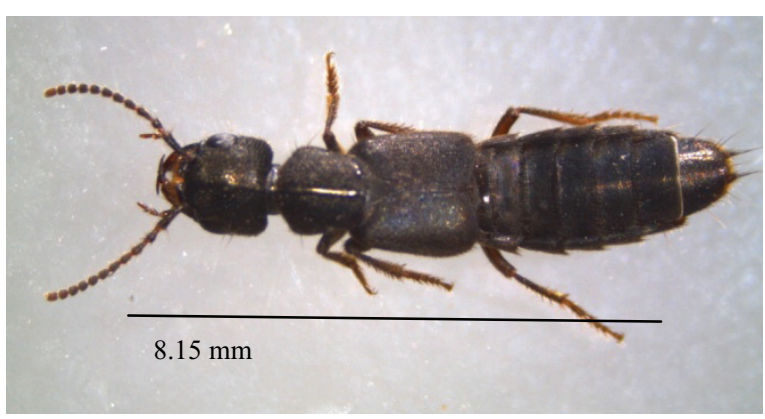

n. Staphy sp14

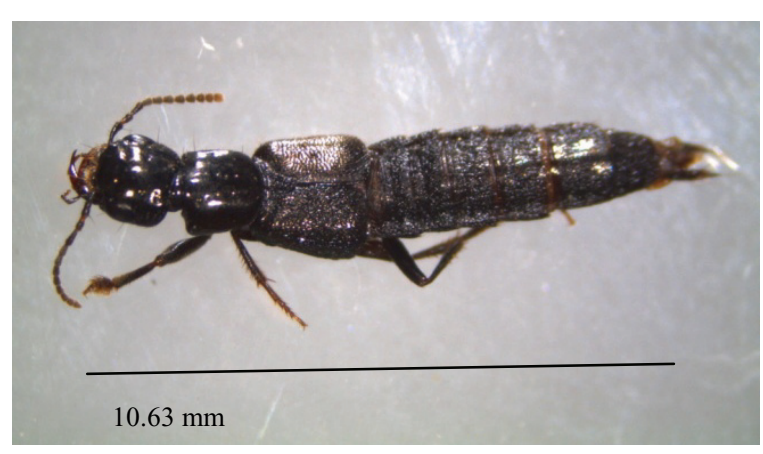

p. Staphy sp16

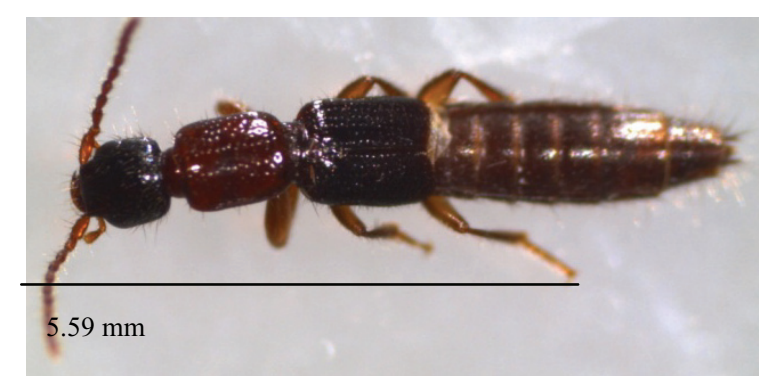

r. Staphy sp 18 


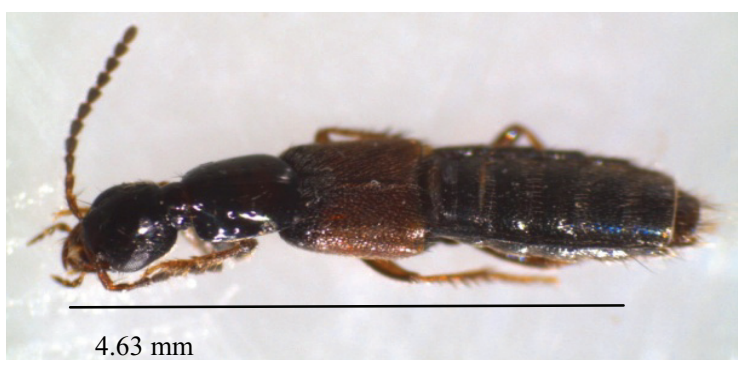

s. Staphy sp19

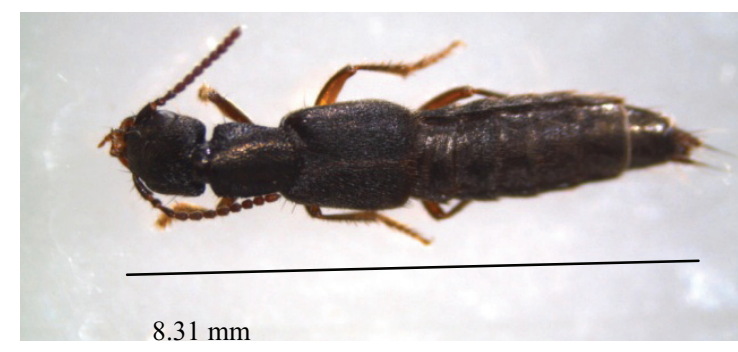

u. Staphy sp21

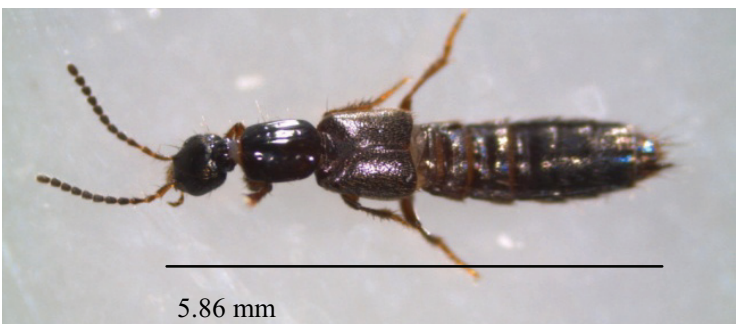

w. Staphy sp23

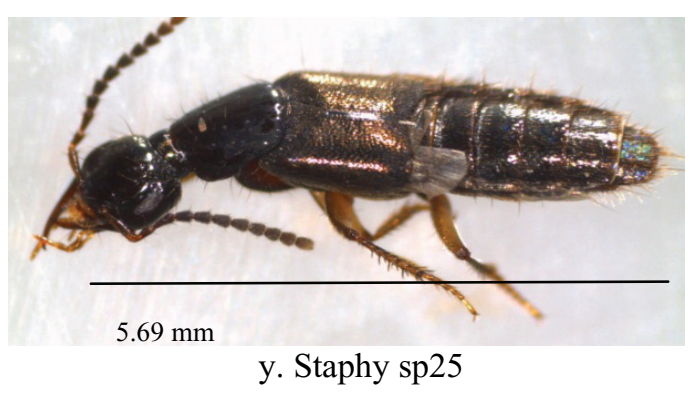

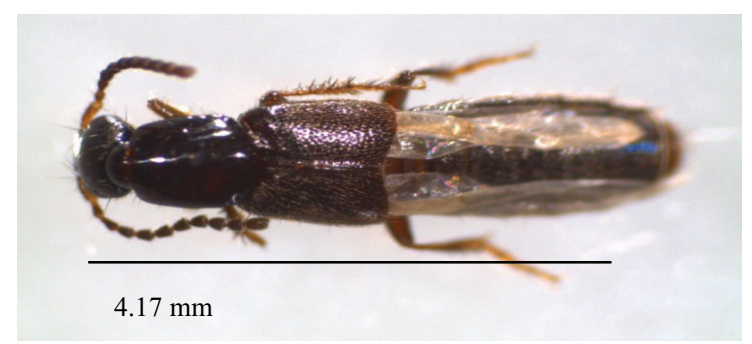

t. Staphy sp20

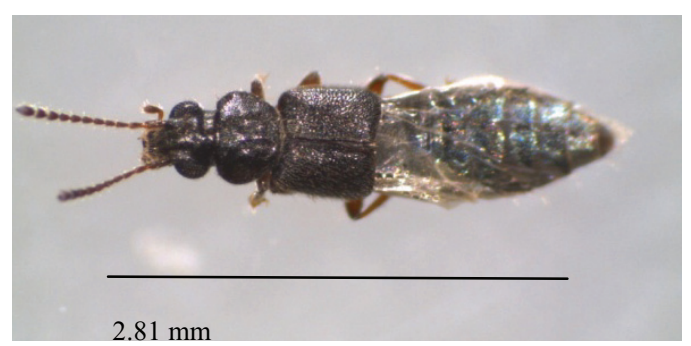

v. Staphy sp22

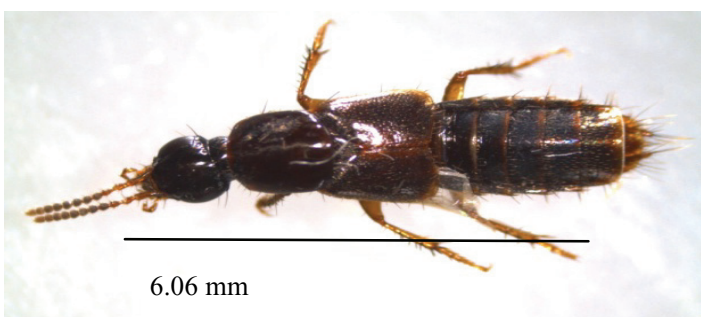

x. Staphy sp24

Figure 4a-y. Unidentified intertidal rove beetles collected from Bachok's coast. 


\section{DISCUSSION}

Rove beetles in this study were collected by light traps. During sampling most of the staphylinids gathered at the bottom of the net of the light trap and were rarely seen in flight. This could be due to the strong wind blowing at the beach.

Results of this study show that Pantai Irama had the lowest species richness, diversity and abundance of staphylinid beetles. Pantai Irama is a tourist sport with development to support tourism such as a number of lodgings, food stalls, and souvenir shops. The beach has many people swimming and facilities for water sport activity. This disturbed habitat explained the moderate diversity of intertidal staphylinids at Pantai Irama compared to staphylinid at Pantai Kemasin, Pantai Perupok, Pantai Nipah, Pantai Tanjung Chap and Pantai Melawi. Pantai Tok Bali is also disturbed being a popular spot for picnic and swimming explaining the lower diversity value of intertidal staphylinids at Pantai Tok Bali. The type of vegetation between the different beaches are the same but this factor did not affect the intertidal staphylinids. Abdullah and Sina [7] in their study of staphylinid fauna of Lanjak Entimau, Sarawak, Borneo island, reported that moisture and abundance of decaying materials affect the composition of staphylinid assemblage.

From this study, 885 specimens were caught and only 8 species were identified. The remaining 26 species could not be identified with probably some new species. There is a considerable lack of literature and descriptions related to the study of intertidal rove beetle ecology and diversity. Studies of insects along the seashore have been conducted by Bigot [8], Caussanel [9], Polhemus and Evans [10], Saunders [11], Spilman [12], Whitehead [13] and Wong \& Chan [6]. Meanwhile Jeon and Ahn [14] reported that 442 species of Staphylinidae in 102 genera and 7 subfamilies are known to be confined to seashore habitats or $0.93 \%$ of the circa 47,744 described species of Staphylinidae $[15,16]$.

Overall, the diversity and abundance of intertidal rove beetles of Bachok's coast were high, probably due to the low level of human disturbance. Most of the time the coastal areas were used by fishermen as their boat depot except for Pantai Irama and Tok Bali which has been developed for tourism and recreational purposes.

Throughout the sampling period intertidal rove beetles were hardly found wandering on the sandy beach because the adult and larval beetles remained buried in the sand when covered by the tide and they only emerged to form mole-like surface trails and feed upon diatoms when exposed [17]. Their eggs and young larvae were placed in the special maternal burrows, while the larger larvae and non-breeding adults had their own individual burrows [17]. Charles and Roberta [17] reported that both adults and larvae of Psamathobledius punctatissimus became comatose when in direct contact with water and recovered after six hours of submergence.

This is the first study conducted at Bachok coastal area on intertidal staphylinid beetles. This study was part of an expedition carried out by Institute of Ocean and Earth and Sea (IOES) to survey and inventorize the biodiversity of Kelantan's coastal area.

\section{ACKNOWLEDGEMENTS}

The author would like to express gratitude to research assistants, Azman Abdol Hamid, Ibnu Sina and Suwati Mat Isa and part timers Fatmahjihan Fauzee and Shamsul Faiz and the Industrial trainees Mohd Shukri Mohd Sabri, Ainor Faradzilah Mohamad Fuad and Nurul Atikah Abu Bakar for assistance in the field. This study was supported by FRGS grant No: FP 002/2008C.

\section{REFERENCES}

1. Newton, A.F., Thayer, M.K., Ashe, J.S., Chandler, D.S., (2000). 22. Staphylinidae Latreille, 1802. In: Arnett, R.H., Thomas, M.C., (Eds.), American Beetles, Vol. 1. Archostemata, Myxophaga, Adephaga, Polyphaga: Staphyliniformia. CRC Press, Boca Raton, FL, pp. 272-418.

2. Hammond, P. M. (2000). Coastal Staphylinidae (rove beetles) in the British Isles, with special reference to saltmarshes, In B. R. Sherwood, B. G.Gardiner and T. Harris $[E d s$.$] , British$ Saltmarshes. Joint symposium on British Saltmarshes organized between the Linnean Society of London, the Royal Society for the Protection of Birds, and English Nature (London; 2000). Cardigan; Forrest Text. pp. 247302.

3. Moore, I. and E.F. Legner, (1976). Intertidal Rove Beetles (Coleoptera, Staphylinidae). In: Marine Insects, Cheng, L. (Ed.). North Holland Publisher, Amsterdam, pp. 521-546.

4. Ahn, K.J. and J.S. Ashe, (1996). Phylogeny of the intertidal aleocharine tribe Liparocephalini (Coleoptera: Staphylinidae). Syst. Entomol., 21:99-114

5. Ahn, K.J. and J.S. Ashe, (2004). Phylogeny of the Myllaernini and related taxa (Coleoptera: 
Staphylinidae: Aleocharinae). Cladistics, 20:123-13

6. Maruyama M., Klimaszewski J. \& Gusarov V. (2008). Osakatheta yasukoae, a new intertidal genus and species of athetine rove beetles (Coleoptera, Staphylinidae, Aleocharinae) from Japan. Zootaxa 1683: 39-50

7. Wong M. H. \& Chan T. D. (1977). The ecology of the marine rove beetle, Bryothinusa spp. (Coleoptera: Staphylinidae) in Hong Kong. Hydrobiologia 53(3): 253-256

8. Abdullah F. and I. Sina, (2009). Rove Beetles (Coleoptera: Staphylinidae) of Lanjak Entimau, Sarawak, East Malaysia. International Journal of Zoological Research. 5(3): 126-135, 2009 ISSN 1811-9778@2009 Academic Journals Inc.

9. Bigot, L. (1970). Contribution à l"étude écologique des peuplements halophiles de la région de Tuléar (Madagascar). II) La plage et le Cordon dunaire. Ann. Univ. Madagascar. pp. 159-163.

10. Caussanel, C. (1965). Recherches préliminaries sur le peuplement de Coléopteres d"une plage sableuse Atlantique. Ann. Soc. ent. Fr. 1: 197248

11. Polhemus, J. T. \& Evans, W. G. 1969. A new genus of intertidal Saldidae from the Eastern Tropical Pacific with notes on its biology (Hemiptera). Pacif. Insects. II:271-578

12. Saunders, L. G. (1928). Some marine insects of the Pacific coast of Canada. Ann. Ent. Soc. Am. XXI:521-545.

13. Spilman, T. J. (1967). The heteromerous intertidal beetles (Coleoptera: Salpingidae: Aegialitinae). Pacif. Insects. 9:1-21

14. Jeon M.J. and Ahn K.J. (2007). Description of late-instars of three littoral Cafius species (Coleoptera:Staphylinidae) by association of life stage with DNA. Florida Entomologist 90(3). $465-474$

15. Herman, L. H. (2001). Catalog of the Staphylinidae (Insecta: Coleoptera). 1758 to the end of the second millennium. V. Staphylinine Group (Part 2). Bull. Am. Mus. Nat. Hist. 265: 2441.

16. Christopher G. M. and Klimaszewski, J. (2008). Introduced Staphylinidae (Coleoptera) in the Maritime Provinces of Canada. The Canadian Entomologist 140(1): 48-72.

17. Charles, L.G \& Roberta, J.G. (1983). Biology and distribution of the littoral rove beetles Psamathobledius punctatissimus (Le Conte) (Coleoptera:Staphylinidae). Hydrobiologia 101(3): 203-214. 